\title{
German Students' Environmental Literacy in Science Education Based on PISA Data
}

\author{
Volkan Hasan Kaya*, Doris Elster \\ Department Biology Education, Institute of Science Education, University of Bremen, Germany \\ *Corresponding Author: volk.has.an@gmail.com
}

\section{ABSTRACT}

The main aim of this study was to determine the factors that affect the environmental literacy (EL) of 15-year-old students in Germany. The data were based on findings from the PISA 2015 of German students $(n=6.504)$, which were published on the official PISA site (http://www.pisa.oecd.org). According to the results, there was a positive and meaningful relationship between EL and environmental optimism (EO) at a low level. There was a meaningful relationship between EL and socioeconomic characteristics (SEC). Moreover, SEC has a large effect on the EL. There was a significant relationship between both classic literature and books on art, music, or design that students have at home, number of musical instruments at home, and EL. There was, however, no significant relationship between both 'books of poetry' and 'books to help with school work that students have at home' and EL . Results show that there was a significant relationship between some of the selected teaching characteristics (frequency of adapting lessons, teachers' providing individual help, teachers' explanations of scientific ideas, and teacher changing the structure) and EL, while there was no significant relationship between EL and teachers continuing frequency of teaching. Recommendations for the promotion of EL in schools are discussed.

KEY WORDS: environmental education; environmental literacy; PISA; science education

\section{INTRODUCTION}

厂 n 2005, the UNESCO launched its Decade of Education for Sustainable Development (2005-2014). In this decade, educational institutions in Germany increased their efforts to educate students for a more sustainable future. In the PISA 2015, the scientific literacy of German students averaged 509 points, 16 points over the OECD average, while for PISA 2000, their average was 487 points, 13 points below the OECD average. Comparing these two outcomes raised the following idea about this positive change on science literacy. According to PISA data, it was determined that certain factors must have a positive and/or negative effect on environmental literacy (EL). Therefore, the purpose of this study was to determine the relationships between the environmental optimism (EO), socioeconomic characteristics (SEC) of the participating students, teaching characteristics (TC), and EL of 15-yearold students in Germany. The data were based on the German sample of PISA 2015. The following sections will discuss environmental education (EE) in Germany's educational system.

\section{EDUCATIONAL SYSTEM AND EE IN GERMANY}

In our globalized world, social life is more and more determined by the natural sciences and the technologies. The task of science education (SE) is to educate citizens who are able to participate in a challenging world (Bybee and
Fuchs, 2006). The goal of SE is not only to educate future scientists but also to teach scientific literacy to all students (Roberts, 2007). These considerations form the basis for the National Educational Standards for secondary level biology and the other natural sciences (KMK, 2005). These standards constitute a general recommendation that all schools help students to achieve a common level of learning (Barton, 2009). In 2003-2004, the Council of Ministers (KMK) developed the National Educational Standards for Science (biology, chemistry, and physics) for grades 9-10 in secondary school, and in 2007, additional standards for upper secondary school for all 16 German federal states (OECD, 2010).

An introduction to Germany's educational system will allow for a better understanding of the importance of national education standards. Therefore, the following section will discuss Germany's educational system.

Primary and secondary schools depend on local governments, and high schools (vocational schools) depend on state governments. The management and regulation of the educational system are the responsibility of the states (Bal and Basar, 2014). All children who are 6 years old are required to go Grundschule (primary school) for 4 years (Venter, 1987; Hainmüller, 2003). Germany's educational system is a bit complicated because the secondary level is divided into two levels (Hainmüller, 2003). Realschule is the lower secondary school, and the Gymnasium is an academic school that combines the lower and upper secondary levels (Halász et al., 2004). Gymnasium is the only type of school in Germany's 
otherwise very heterogeneous school system that is found in all 16 federal states (Pant et al., 2013).

In the Realschule, students are provided with the opportunity to learn about daily life and vocational life. At the Gymnasium, students are also given vocational training and are trained for academic careers (Kocak and Cobanogullar1, 2016). In the Federal Republic of Germany, students are required to pass the Abitur examination to enter higher education institutions and graduate from the Gymnasium upper secondary level (Turan, 2005).

Each of the 16 federal states has its own individual school system, educational aims, and educational and administrative traditions; however, every educational administration is organized in a centralized way regarding school structure, kinds of school, and curriculum (Huber and Gördel, 2006). Eurydice (2010) mentions that teaching in schools in Germany is governed by regulations of various kinds laid down by the federal states. The proposed curriculum includes knowledge about the use of materials and various teaching approaches. Moreover, with the Education for Sustainable Development initiated by the UNESCO, curriculum, especially science curriculum, has been focused on educating more qualified environmental literate individuals.

In the last decade, educational institutions around the world to include German educational institutions have attempted to increase their efforts to educate students for a more sustainable future. For this reason, the term environmental sustainable development (ESD) has evolved out of EE (Filho, 2009), meaning that EE is linked to the concept of sustainable development (Brößkamp, 1994, as cited in Schleicher, 1995). ESD concerns lifestyles, participation, values, global, and individual responsibility, and patterns of consumption and production. ESD enables sustainable action and encourages readiness to accept responsibility for one's own actions (UNESCO, 2014). Since 1996, ESD has been a field of learning and action (Haan et al., 2007).

In 2003, the German Commission for UNESCO decided on the Hamburg Declaration. The Declaration invited governmental and non-governmental organizations in Germany to participate in an "alliance for learning sustainability." The purpose was to develop an action plan for the UN Decade. In 2005, the National Plan of Action was to establish the notion of sustainable development permanently in all stages of education (UNESCO, 2014). This plan was supplemented by over 60 specific educational policy measures. It includes necessary skills and competencies such as critical thinking, imagining future scenarios, and making decisions in a collaborative way. These competencies are necessary for environmentally literate individuals. In 2007, over 200 European and international representatives participated the conference "UN Decade of Education for Sustainable Development - the Contribution of Europe" in Berlin, Germany, during the German Presidency of the EU Council. The primary objective of the conference was to identify the European contribution to the UN Decade.
2 years later, in 2009, the "World Conference on Education for Sustainable Development" was held in Bonn, Germany. 700 participants from 150 countries agreed to the Bonn Declaration that was launched by the UNESCO and the German Federal Ministry of Education and Research. In 2014, the "World Conference on Education for Sustainable Development: Learning Today for a Sustainable Future" in Aichi-Nagoya, Japan, marked the end of the UN Decade. It celebrated its achievements and launched the Global Action Program on Education for Sustainable Development (2015-2019).

The following section will discuss the development of the purpose of this research.

\section{THE PURPOSE OF THE RESEARCH}

Literacy, especially scientific literacy, is of paramount importance to PISA. However, although its scientific literacy tasks include items related to environmental issues, it does not evaluate EL directly. A literature review found international empirical research on students' EL (Fah and Sirisena, 2014; Spínola, 2015) and the EL of teachers and teacher candidates (Pe'er et al., 2007; Tuncer et al., 2009; Yavetz et al., 2009; Derman et al., 2016). Researchers have developed scales to assess EL (Ozsevgec et al., 2010; Atabek-Yigit et al., 2014). However, it seems that there is not enough research on EL using PISA data. In the future, PISA will provide an opportunity to survey EL in different nations. Moreover, Lin and Shi (2014) suggested that further investigations are needed to refine the understanding of socioeconomic influences on EL. Hollweg et al. (2011) believed that information about students' home situations, especially family SEC and school experience, may be relevant to understanding EL. For instance, one of the components of economic, social, and cultural status in PISA appears to be the index of home possessions that include variable of the number of books in the home (Recommendations to the National Center for Education Statistics, 2012). In this study, the relationship between the SEC and EL was investigated. SEC includes income as well as subjective perceptions of education level, financial security, social status, and social class (American Psychological Association, 2017). Therefore, in recent years, the number of books in the household was added to SEC indexes (OECD, 2004; Taylor and Yu, 2009; Zhao et al., 2012). Bearing this in mind, this empirical study examines EL in SE. The following sections will discuss scientific literacy as a main concept in PISA and framing the concept of EL.

\section{SCIENTIFIC LITERACY AS A MAIN CONCEPT IN PISA}

Although the Paris-based Organization for Economic Cooperation and Development (OECD) sponsors PISA, both OECD members and non-OECD countries participate (Bybee and McCrae, 2011). PISA offers opportunities to improve and compare the performance of these nations' educational systems (OECD, 2003). The first PISA survey was launched in 2000, 
and this survey has been repeated with its focus shifting from mathematics to science to reading every 3 years (OECD, 2000b). Thus, PISA provides data on the specific knowledge and skills of students, schools, and nations about these forms of literacy (Dobrota et al., 2015). Scientific literacy was the main topic of PISA 2015. The international student assessments provide significant information about SE policies, programs, and practices in different nations (Bybee and McCrae, 2011). The most concrete example is the changing definition of scientific literacy. Scientific literacy was first defined by PISA 2000 as "The ability to employ scientific data, to determine questions, and to obtain evidence-based conclusions for comprehending and helping make decisions regarding the natural world and the alterations made to the natural world by human activities" (OECD, 2000a. p. 76; OECD, 2002a. p. 102). PISA 2000 added "The ability to use scientific knowledge, to identify science questions, to understand the nature of scientific investigation, to use scientific evidence, and to communicate these aspects of science are assessed as scientific literacy by PISA" (OECD, 2002b. p. 211). Therefore, distinctive features of science literate individuals are to understand scientific concepts, to have the ability to adopt a scientific perspective, and to think scientifically about evidence (OECD, 2004). In PISA 2006, science was assessed more comprehensively. The main difference was the distinction between knowledge of science and knowledge about science (OECD, 2009a). In 2006, the definition of scientific literacy was as follows:

The scientific competency of a person and employing that competency to determine questions, to learn new scientific details, to elaborate scientific elements, and to obtain evidencebased conclusions regarding scientific topics, comprehending the characteristics of science as a form of human knowledge and enquiry, awareness of how our material, and intellectual and cultural environments is formed by science and technology and willingness to play a role in scientific subjects as a reflective citizen with scientific ideas (OECD, 2006. p. 12; OECD. 2013. p. 17).

By the year 2015, scientific literacy was defined by PISA as: The ability to play a role in scientific matters as a reflective citizen with scientific ideas. A person with sufficient scientific competency is willing to take part in a reasoned and scientific and technological discourse requiring the scientific explanations of scientific matters, evaluation of scientific research and its design, and scientific interpretations of data and evidence (OECD, 2016. p. 20).

Ultimately, scientific literacy is constantly evolving. The necessity of scientific knowledge, especially the evidencebased knowledge in the definition of SL was foregrounded by PISA 2000. The importance and characteristics of science have become more specified in PISA 2006 and 2015. It is predicted that future discussions of SE, especially EL, will include environmental issues, their significance, and their components. For this reason, international assessment research will be able to evaluate EL and scientific literacy directly.

\section{FRAMING THE CONCEPT OF EL}

Human consumption, agriculture, and technology make life more comfortable and safe but also harm the environment (Polat et al., 2014). Therefore, deficient individual understanding of the fundamental environmental problem is often cited as a cause of environmental deterioration (Schneider, 1997). Currently, we face extremely important environmental problems such as increased air pollution (Ivanova and Roy, 2007), extinction of plants and animals (Patz et al., 2003), clearing forests (UNESCO-UNEP, 1992), water shortages (Goss, 2010), greenhouse gases (Chivian and Bernstein, 2010), genetically modified organisms (GMO) (Key et al., 2008; Hedrick, 2001), and acid rain (Likens and Bormann, 1974). These problems affect not only human beings but also all living things. Therefore, we need more environmentally literate individuals. We also need them to adapt to the changes and dynamics of environmental resources and systems (Scholz, 2011). EL is the capacity to recognize and understand the actual ecological situation and to take appropriate action to maintain, restore, and improve the health of environmental systems (Roth, 1992). EL as a part of the scientific literacy gives individuals the ability to engage with science-related issues and scientific ideas (PISA, 2013).

In 1990, the term of EL was clarified and redefined with the development of EE (Roth, 1992). However, researchers continue to present new definitions of this concept. One such definition is as follows:

A person competent in terms of the environment who spreads and implements primary ecological concepts and principles knows how human activities affect the environment from an ecological perspective, possesses the skills needed to define and investigate environment-related issues and alternative solutions, and adopts environmental values necessary for responsible use of environmental resources. (Subbarini, 1998. p. 245).

As the North American Association EE informs us, EL includes dispositions, knowledge, and competencies applied for the purpose of responsible environmental behavior (Daniš, 2013). Ultimately, people should be aware of nature's laws and sensitive to environmental problems and communicate with nature through EL (Kaya and Kazanc1, 2009).

This research investigated the impact of environmental awareness (EA), environmental responsibility (ER), and $\mathrm{EO}$ on EL. The researchers reveal the basic framework for understanding EL in the light of the PISA 2015 data. One of the components, EA, is a basic level of EE (Coyle, 2005). Development of EA prepares students to become adults who have more knowledge and understanding of the environment (David, 1974). Environmentally literate individuals have social awareness about their own actions, as well as EA (Stoller-Patterson, 2012). Another component of EL and ER is defined as "an individual's responsible and moral approach to the prevention of environmental degradation, the solution of environmental issues and willingness to act in a positive 
manner for the environment" (Wenshun et al., 2011. p. 992). The last component, EO, has gained significance in the field of EE (Eryigit et al., 2011) because students' levels of EO as well as their EA affect their environmental concerns and this affects the global climate, the economy, and society (PISA, 2017). Finally, this research intends to contribute to a better understanding of EL by analyzing the effects of EA, ER, and $\mathrm{EO}$ in EE.

\section{RESEARCH QUESTIONS}

The main aim of this research is to determine the factors that affect the EL of 15-year-old students in Germany. More specifically, its research questions were:

- Which factors affect EL of 15-year-old German students?

- What is the relationship between EL and SEC of the students (such as type of books and number of musical instruments at home)?

- What is the relationship between the EL and TC (such as explanations, individualized help, and the structure of lessons)?

\section{RESEARCH METHODS AND DESIGN}

This study used the paradigm of descriptive research, and the surveys were used descriptively. In this study, the target population was 15 -year-old German school students. The sample consists of the 6,504 students PISA 2015 data obtained from the official PISA website (http://www.pisa.oecd.org).

\section{Data Analysis}

This section consists of two parts. The first describes the development of the scales. The second explains the analyses used in this study. The EL and EO scales were developed in two stages, first exploratory and then confirmatory factor analysis. Two different scales were developed by the researchers because the Likert-type items for EO differ from other factors.

\section{Developing the Scales}

In the first part of the scale development, exploratory factor analysis (EFA) with the Statistical Package for the Social Sciences (SPSS) software (SPSS version 24) was used to examine the construct validity of the scale. In the second part, confirmatory factor analysis with analysis of moment structures (AMOS) software (AMOS version 18) revealed the relationships between the variables.

\section{EFA for EL}

To determine whether or not to perform factor analysis, the Kaiser-Meyer-Olkin (KMO) Value and Bartlett's test of sphericity were calculated before the EFA. KMO values over $0.50(\mathrm{KMO}=0.90, \rho<0.01)$ indicate that factor analysis sampling was appropriate. Bartlett's test of sphericity was significant at 3,2061.74, $\rho<0.01$, showing that the tool can be differentiated into factor structures. The t-test for the reliability of the meaningfulness of the median of top $27 \%$ and bottom $27 \%$ groups was done. The results are shown in Appendix 1, and the t-values are meaningful $(\rho<0.01)$. These results indicate that it is appropriate to perform a factor analysis. As Appendix 2 highlights, there are two important factors in the scale. While there are two factors in the graph with a high acceleration, the general trend of the graph in the third and subsequent factors is horizontal, and they have no significant declining trend. Thus, the contribution of the third and subsequent factors to the variance is very close to each other. According to EFA, it is seen that the 13-items were aggregated on the two factors, where eigenvalue is $>1$ (Appendix 2). The factor common variance, factor-1 load value, and the analysis of converted basic components are presented in Table 1.

According to the results of EFA, it was obtained that 13-items were loaded on the two factors labeled. Whole factors explained $55.2 \%$ of the total variance. Through factor analysis, an attempt was made to bring together variables that measure the same structure with a small number of factors (Büyüköztürk, 2009). Item loads larger than 0.52 were chosen for inclusion in the scale. No items were excluded from the scale because they were not disassociated. As shown in Table 1, the item loads for each factor were organized from the high value to low value. The total variance was $55.2 \%$. The variances of environmental awareness (EA) and environmental responsibility (ER) were found to be $29.2 \%$ and $25.9 \%$, respectively. Analysis of factors- 1 and -2 found Cronbach's alpha internal consistency coefficients of 0.85 for EA and 0.84 for ER. As Appendix 3 shows, there seems to be a positive and meaningful relationship between EA, ER, and EL $(\rho<0.01)$.

\section{EFA for EO}

A KMO value over $0.50(\mathrm{KMO}=0.81, \rho<0.01)$ indicates that factor analysis sampling was appropriate. Bartlett's test of sphericity was significant at $8,370.62, \rho<0.01$, which shows that the tool can be differentiated into factor structures. The $t$-tests for the reliability of the meaningfulness of the median of top 27\% and bottom 27\% groups were done (Appendix 4). Appendix 4 shows that the t-values were meaningful $(\rho<0.01)$ except for item 5, which was excluded in the scale. According to the eigenvalue, the number of important factors in the scale was one (Appendix 5). According to EFA, it was seen that the 6-items were made on the 1 factor, where eigenvalue is $>1$ (Appendix 5). the factor common variance, factor-1 load value, and the analysis of converted basic components are presented in Table 2.

According to the result of EFA, it is obtained that six items were loaded on the factor- 1 labeled. Whole factors explained $45.9 \%$ of the total variance. Those item loads larger than 0.55 were chosen and included in the scale. No items were excluded from the scale because they were not disassociated. The Cronbach's alpha internal consistency coefficient was 0.77 for factor- 1 .

\section{CONFIRMATORY FACTOR ANALYSIS FOR EL AND EO}

Structural validity was tested by confirmatory factor analysis as described above. The initial results obtained by confirmatory factor analysis indicated that some of the values were not within 


\begin{tabular}{|c|c|c|c|c|c|c|}
\hline \multirow[t]{2}{*}{ Factor } & \multicolumn{2}{|r|}{ Item } & \multirow[t]{2}{*}{$\begin{array}{l}\text { Factor common } \\
\text { variance }\end{array}$} & \multirow[t]{2}{*}{ Factor-1 load value } & \multicolumn{2}{|c|}{$\begin{array}{l}\text { Analysis of converted basic } \\
\text { components }\end{array}$} \\
\hline & & & & & Factor-1 & Factor-2 \\
\hline \multirow[t]{7}{*}{$\begin{array}{l}\text { Environmental } \\
\text { responsibility }\end{array}$} & 1 & $\begin{array}{l}\text { How informed are you about this } \\
\text { environmental issue? Air pollution }\end{array}$ & 0.67 & 0.68 & 0.81 & \\
\hline & 2 & $\begin{array}{l}\text { How informed are you about this } \\
\text { environmental issue? Extinction of } \\
\text { plants and animals }\end{array}$ & 0.62 & 0.66 & 0.78 & \\
\hline & 3 & $\begin{array}{l}\text { How informed are you about } \\
\text { this environmental issue? The } \\
\text { consequences of clearing forests } \backslash \\
\text { other land use }\end{array}$ & 0.63 & 0.68 & 0.78 & \\
\hline & 4 & $\begin{array}{l}\text { How informed are you about this } \\
\text { environmental issue? Water shortage }\end{array}$ & 0.56 & 0.64 & 0.74 & \\
\hline & 5 & $\begin{array}{l}\text { How informed are you about this } \\
\text { environmental issue? Nuclear waste }\end{array}$ & 0.54 & 0.64 & 0.72 & \\
\hline & 6 & $\begin{array}{l}\text { How informed are you about this } \\
\text { environmental issue? The increase of } \\
\text { greenhouse gases in the atmosphere }\end{array}$ & 0.49 & 0.64 & 0.67 & \\
\hline & 7 & $\begin{array}{l}\text { How informed are you about this } \\
\text { environmental issue? The use of } \\
\text { GMO }\end{array}$ & 0.33 & 0.56 & 0.52 & \\
\hline \multirow[t]{6}{*}{$\begin{array}{l}\text { Environmental } \\
\text { awareness }\end{array}$} & 8 & $\begin{array}{l}\text { Identify the science question } \\
\text { associated with the disposal of } \\
\text { garbage }\end{array}$ & 0.63 & 0.62 & & 0.78 \\
\hline & 9 & $\begin{array}{l}\text { Interpret the scientific information } \\
\text { provided on the labeling of food } \\
\text { items }\end{array}$ & 0.60 & 0.58 & & 0.77 \\
\hline & 10 & $\begin{array}{l}\text { Predict how changes to an } \\
\text { environment will affect the survival } \\
\text { of certain species }\end{array}$ & 0.56 & 0.61 & & 0.72 \\
\hline & 11 & $\begin{array}{l}\text { Recognize the science question that } \\
\text { underlies a newspaper report on a } \\
\text { health issue }\end{array}$ & 0.53 & 0.57 & & 0.71 \\
\hline & 12 & $\begin{array}{l}\text { Identify the better of two } \\
\text { explanations for the formation of } \\
\text { acid rain }\end{array}$ & 0.15 & 0.55 & & 0.70 \\
\hline & 13 & $\begin{array}{l}\text { Describe the role of antibiotics in the } \\
\text { treatment of disease }\end{array}$ & 0.51 & 0.57 & & 0.69 \\
\hline
\end{tabular}

the acceptable limits. For this reason, covariance was created between the error terms of the items within each latent variable in the model. These findings are shown in Table 3. Each correction should be based on a theoretical basis (Meydan and Sesen, 2015; Karagoz, 2016). Therefore, the error terms of the items in each factor were associated (Karagoz, 2016). Then, confirmatory factor analysis was performed again. Corrected confirmatory factor analysis seems to have good fit in general. Good fit and acceptable fit have different value ranges. Furthermore, it is possible that a model may fit the data, although one or more fit measures may suggest bad fit (Schermelleh-Engel et al., 2003).

As Table 3 shows, the significance value was found to be 0.00 . Moreover, the $\rho$-values and most of the other values may be interpreted as indicating good fit.

\section{Findings}

The results of the analysis are displayed in the tables according to whether they are statistically significant or not. Cohen's d (for $t$-test) and Cohen's f (for ANOVA) effect sizes were used to calculate effect size. The findings are discussed in three sections: Factors in EL, SEC, and TC that influence EL.

\section{FINDINGS ABOUT THE FACTORS IN EL}

In this research, exploratory and confirmatory analyses were used to evaluate the data derived from the analysis of quantitative data. As Appendix 6 shows, the students had high EO $(X=2.46 / 4.00)$, while EA $(X=2.86 / 4.00)$ and ER $(X=2.28 / 4.00)$ were low. Appendix 7 indicates that there seems to be a positive and meaningful relationship between $\mathrm{EL}$ and EO at a low level $(\mathrm{r}=0.16, \rho<0.01)$. As Appendix 8 highlights, there was a positive correlation between the EL of students and EA, ER, and EO. An increase in one of these three factors affects EL positively.

As Appendix 9 shows, when the factors related to the EO of the German students were examined, the factor of the extinction 


\section{Table 2: Factor analysis}

\begin{tabular}{|c|c|c|c|c|}
\hline \multirow{2}{*}{$\begin{array}{l}\text { Factor } \\
\text { Environmental } \\
\text { optimism }\end{array}$} & \multicolumn{2}{|r|}{ Item } & \multirow{2}{*}{$\begin{array}{c}\text { Factor common variance } \\
0.49\end{array}$} & \multirow{2}{*}{$\frac{\text { Factor-1 load value }}{0.70}$} \\
\hline & 1 & $\begin{array}{l}\text { This issue will improve or get worse over next } 20 \text { years? } \\
\text { Extinction of plants and animals }\end{array}$ & & \\
\hline & 2 & $\begin{array}{l}\text { This issue will improve or get worse over next } 20 \text { years? The } \\
\text { increase of greenhouse gases in the atmosphere }\end{array}$ & 0.58 & 0.76 \\
\hline & 3 & $\begin{array}{l}\text { This issue will improve or get worse over next } 20 \text { years? } \\
\text { Clearing of forests for other land use }\end{array}$ & 0.52 & 0.72 \\
\hline & 4 & $\begin{array}{l}\text { This issue will improve or get worse over next } 20 \text { years? Air } \\
\text { pollution }\end{array}$ & 0.39 & 0.62 \\
\hline & 5 & $\begin{array}{l}\text { This issue will improve or get worse over next } 20 \text { years? The } \\
\text { use of GMO }\end{array}$ & 0.49 & 0.70 \\
\hline & 6 & $\begin{array}{l}\text { This issue will improve or get worse over next } 20 \text { years? } \\
\text { Nuclear waste }\end{array}$ & 0.30 & 0.55 \\
\hline
\end{tabular}

Explained variance total $45.9 \%$, Cronbach's alpha 0.77 , GMO: Genetically modified organisms

\begin{tabular}{|c|c|c|c|c|}
\hline Model Fit Summary & Good fit & Acceptable fit & EL model fit & EO model fit \\
\hline $\mathrm{c} 2 / \mathrm{sd}$ & $0 \mathrm{~d} / 2 / \mathrm{sd} \mathrm{dd}$ & $2 \mathrm{dd}^{2} / \mathrm{sd} \mathrm{dd}$ & 8.83 & 28.22 \\
\hline$\rho$ & $0.05 \leq \rho \leq 1$ & $0.012 \rho \leq 0.012$ & 0.00 & 0.00 \\
\hline Root mean square error of approximation & Orror of app & $0.05 \mathrm{r}$ of approx & 0.04 & 0.07 \\
\hline Normed fit index & 0.95 indexappr & 0.90indexappr & 0.99 & 0.99 \\
\hline Tucker-Lewis index & $0.95 \times \mathrm{r}$-Lewis & $0.90 \times \mathrm{r}$-Lewis o & 0.98 & 0.95 \\
\hline Comparative fit index & 0.97indexve & 0.95 indexve & 0.99 & 0.99 \\
\hline Relative fit index & $0.90<\mathrm{RFI}<1.00$ & $0.85<\mathrm{RFI}<0.90$ & 0.98 & 0.95 \\
\hline
\end{tabular}

of plants and animals with a coefficient of 1.67 had the highest factor value in PISA 2015. The students seemed to perceive $\mathrm{EO}$ as air pollution, clearing forests, and greenhouse gases. The last item is GMO with a coefficient of 1.00. Moreover, this research argues that students should be more informed and encouraged to take responsibility for environmental issues, particularly, GMO and water shortages.

\section{FINDINGS ABOUT THE SEC THAT INFLUENCE EL}

This section includes analyses of the students' SEC. Parametric tests, ANOVA, and the $t$-test were used to evaluate the data derived from the analysis of quantitative data (Table 4).

There was a significant relationship between both classic literature and books on art, music, or design that students have at home and $\mathrm{EL}\left(\mathrm{t}_{\text {Classic Literature }}(5.500)=3.86 . \mathrm{t}_{\text {Art }}\right.$, music or design $(5.544)=3.31, \rho<0.01)$. However, there was no significant relationship between both books of poetry and books to help with school work that students have at home and EL ( $\mathrm{t}_{\text {Poetry }}$ $\left.(5.554)=2.06, \mathrm{t}_{\text {School Work }}(5.621)=1.35, \rho>0.01\right)$. Those who have these types of books at home $\left(\mathrm{X}_{\text {Classic L }}=2.59, \mathrm{X}_{\text {Poetry }}=2.58\right.$, $\mathrm{X}_{\mathrm{BAMD}}=2.59$, and $\mathrm{X}_{\mathrm{BHSW}}=2.58$ ) had a higher average EL than those who did not $\left(\mathrm{X}_{\text {Classic L. }}=2.56, \mathrm{X}_{\text {Poetry }}=2.56, \mathrm{X}_{\mathrm{BAMD}}=2.56\right.$, and $\mathrm{X}_{\mathrm{BHSW}}=2.56$ ) (Table 5).

There was a meaningful relationship between EL and number of musical instruments at home ( $\mathrm{F}[3,5,669]=7.43, \rho<0.01)$. According to the results of the Scheffe test, the EL of students who had 3 or more musical instruments $(d)(X=2.60)$ was more positive than those who had only a single musical instrument (b) $(X=2.56)$ and those who had none (a) $(X=2.56)$ (Table 6).

As Table 6 shows, there was a meaningful relationship between EL and SEC $(\mathrm{t}(5.673)=5.55, \rho<0.01)$. Students' SEC affects their EL. Thus, it can be said that as the SEC increases, EL increases. These results show that SEC has a large effect on the $\operatorname{EL}\left(\eta^{2}=0.18\right)$.

\section{FINDINGS ABOUT THE TC THAT INFLUENCE EL}

This section includes analyses of TC. ANOVA was used to evaluate the data derived from the analysis of quantitative data.

As Table 7 indicates, there is a meaningful relationship between EL and teachers' frequency of adapting the lesson to class needs and knowledge $(\mathrm{F}[3,4,120]=7.18, \rho<0.01)$. According to the results of the Scheffe test, students' EL was higher for students whose teachers adapted lessons to their needs in every lesson or almost every lesson by the teacher $(\mathrm{d})(\mathrm{X}=2.61)$ and lower for those whose lessons were adapted sometimes $(b)(X=2.55)$ or never or almost never (a) $(X=2.55)$.

As Table 8 highlights, there is a meaningful relationship between EL and the frequency of teachers providing individual help when students had difficulties $(\mathrm{F}[3,4.091]=5.08$, $\rho<0.01)$. According to the results of the Scheffe test, the EL of the students who were provided individual help in every lesson or almost every lesson (d) $(X=2.62)$ was higher positive than 


\begin{tabular}{|c|c|c|c|c|c|c|c|c|}
\hline Type of books & Answer & $\mathrm{N}$ & $\bar{X}$ & sd & $\mathrm{Df}$ & $t$ & $\rho$ & $\eta^{2}$ \\
\hline \multirow[t]{2}{*}{ Classic literature } & Yes & 2.363 & 2.59 & 0.27 & 5.500 & 3.86 & 0.00 & 0.03 \\
\hline & No & 3.139 & 2.56 & 0.29 & & & & \\
\hline \multirow[t]{2}{*}{ Poetry } & Yes & 2.952 & 2.58 & 0.28 & 5.554 & 2.06 & 0.04 & 0.02 \\
\hline & No & 2.604 & 2.56 & 0.29 & & & & \\
\hline \multirow[t]{2}{*}{ BAMD } & Yes & 2.928 & 2.59 & 0.28 & 5.544 & 3.31 & 0.00 & 0.03 \\
\hline & No & 2.618 & 2.56 & 0.28 & & & & \\
\hline \multirow[t]{2}{*}{ BHSW } & Yes & 4.943 & 2.58 & 0.28 & 5.621 & 1.35 & 0.18 & 0.02 \\
\hline & No & 680 & 2.56 & 0.28 & & & & \\
\hline
\end{tabular}

MAMD: Books on art, music, or design, BHSW: Books to help with school work

Table 5: The results of ANOVA for EL and number of musical instruments at home

\begin{tabular}{|c|c|c|c|c|c|c|c|c|c|}
\hline Musical instruments & $\mathrm{N}$ & $\bar{X}$ & Source of variance & Df & Mean square & $\mathbf{F}$ & $\rho$ & Sig. Dif. & $\eta^{2}$ \\
\hline None (a) & 1.725 & 2.56 & Between groups & 3 & 0.59 & 7.43 & 0.00 & d-a, d-b & 0.06 \\
\hline 1 (b) & 1.379 & 2.56 & Within groups & 5.669 & 0.08 & & & & \\
\hline $2(\mathrm{c})$ & 1.050 & 2.58 & Total & 5.672 & & & & & \\
\hline 3 and more (d) & 1.519 & 2.60 & & & & & & & \\
\hline
\end{tabular}

\begin{tabular}{|c|c|c|c|c|c|c|c|c|}
\hline SEC & Responses & N & $\bar{x}$ & Sd & Df & $t$ & $\rho$ & $\eta^{2}$ \\
\hline \multirow[t]{2}{*}{ Number of books at home } & $0-25$ & 1.326 & 2.53 & 0.31 & 5.673 & 5.55 & 0.00 & 0.18 \\
\hline & More than 25 & 4.349 & 2.58 & 0.27 & & & & \\
\hline
\end{tabular}

Table 7: The results of ANOVA according to EL and frequency of adapting lessons

\begin{tabular}{|c|c|c|c|c|c|c|c|c|c|}
\hline Adapting lessons & N & $\bar{X}$ & Source of variance & df & Mean square & $\mathbf{F}$ & $\rho$ & Sig. dif. & $\eta^{2}$ \\
\hline Never or almost never (a) & 795 & 2.55 & Between groups & 3 & 0.75 & 7.18 & 0.00 & $d-a, d-b, c-a, c-b$ & 0.07 \\
\hline Some lessons (b) & 1.548 & 2.55 & Within groups & 4.120 & 0.11 & & & & \\
\hline Many lessons (c) & 1.175 & 2.59 & Total & 4.123 & & & & & \\
\hline $\begin{array}{l}\text { Every lesson or almost every } \\
\text { lesson (d) }\end{array}$ & 606 & 2.61 & & & & & & & \\
\hline
\end{tabular}

that of those who did so sometimes (b) $(X=2.55)$, or never or almost never (a) $(\mathrm{X}=2.57)$.

As Table 9 shows, there is a meaningful significant relationship between EL and frequency of teachers explanations of scientific ideas $(\mathrm{F}[3,4.227]=10.91, \mathrm{p}<0.01)$. According to the results of the Scheffe test, the EL of the students whose teachers explained scientific ideas in every lesson or almost every lesson (d) $(\mathrm{X}=2.60)$ was higher than those who did so sometimes (b) $(\mathrm{X}=2.59)$ or never or almost never (a) $(\mathrm{X}=2.52)$.

As Table 10 notes, there is no significant relationship between EL and frequency of teachers continuing to lecture ( $\mathrm{F}[3$, $4.227]=0.98, \rho>0.01)$. Accordingly, it can be said that as the frequency of teachers continuing to lecture increases, EL does not increase.

As Table 11 indicates, there is a meaningful relationship between EL and frequency of teacher changing the structure of lessons to suit class needs $(\mathrm{F}[3,4.078]=4.72, \rho<0.01)$. According to the results of the Scheffe test, the EL of the students whose teachers changed the structure of lessons to suit class needs every lesson or almost every lesson (d) $(X=2.61)$ was higher than that of those whose teachers did so sometimes (b) $(\mathrm{X}=2.55)$.

\section{CONCLUSION AND DISCUSSION}

In this research, parametric tests, ANOVA, and the t-tests were used to evaluate the data derived from the analysis of quantitative data. In this section, the data obtained are discussed in two parts: SEC and TC that influence EL.

Conclusion and Discussion about SEC that Influences EL This study showed there was a significant relationship between EL and the number of musical instruments and books at home (SEC). Oral and McGivney (2013) mentioned that one of the factors thought to affect student achievement is having books 


\begin{tabular}{|c|c|c|c|c|c|c|c|c|c|}
\hline Individual Help & N & $\bar{X}$ & Source of variance & df & Mean square & $\mathbf{F}$ & $\rho$ & $\begin{array}{l}\text { Sig. } \\
\text { dif. }\end{array}$ & $\eta^{2}$ \\
\hline Never or almost never (a) & 1.106 & 2.57 & Between groups & 3 & 0.53 & 5.08 & 0.00 & $d-a, d-b$ & 0.06 \\
\hline Some lessons (b) & 1.603 & 2.55 & Within groups & 4.091 & 0.11 & & & & \\
\hline Many lessons (c) & 986 & 2.58 & Total & 4.094 & & & & & \\
\hline $\begin{array}{l}\text { Every lesson or almost every } \\
\text { lesson (d) }\end{array}$ & 400 & 2.62 & & & & & & & \\
\hline
\end{tabular}

Table 9: The results of ANOVA for EL and the frequency of teachers' explanations of scientific ideas

\begin{tabular}{|c|c|c|c|c|c|c|c|c|c|}
\hline Explanations of scientific ideas & $\mathrm{N}$ & $\bar{X}$ & Source of variance & df & Mean square & $\mathbf{F}$ & $\rho$ & Sig. dif. & $\eta^{2}$ \\
\hline Never or almost never (a) & 550 & 2.52 & Between groups & 3 & 1.10 & 10.91 & 0.00 & d-a, d-b, c-a, c-b & 0.09 \\
\hline Some lessons (b) & 1.573 & 2.56 & Within groups & 4.227 & 0.100 & & & & \\
\hline any lessons (c) & 1.373 & 2.59 & Total & 4.230 & & & & & \\
\hline $\begin{array}{l}\text { Every lesson or almost every } \\
\text { lesson (d) }\end{array}$ & 735 & 2.60 & & & & & & & \\
\hline
\end{tabular}

\begin{tabular}{lcccccccc}
\hline \multicolumn{6}{l}{ Table 10: The results of ANOVA according to EL and frequency of teachers' continuing to lecture } \\
\hline $\begin{array}{l}\text { Teachers' continuing to } \\
\text { lecture }\end{array}$ & $\mathbf{N}$ & $\overline{\mathbf{X}}$ & Source of variance & df & Mean square & $\mathbf{F}$ & $\rho$ & $\begin{array}{c}\text { Sig. } \\
\text { dif. }\end{array}$ \\
\hline Never or hardly ever (a) & 607 & 2.58 & Between groups & 3 & 0.095 & 0.98 & 0.40 & - \\
Some lessons (b) & 1.134 & 2.57 & Within groups & 4.447 & 0.097 & & \\
Most lessons (c) & 1.360 & 2.56 & Total & 4.450 & & \\
Every lesson or almost & 1.350 & 2.58 & & & & & \\
every lesson (d) & & & & & & & \\
\hline
\end{tabular}

\begin{tabular}{|c|c|c|c|c|c|c|c|c|c|}
\hline Changing the structure of lessons & N & $\bar{X}$ & Source of variance & df & Mean square & $\mathbf{F}$ & $\rho$ & $\begin{array}{l}\text { Sig. } \\
\text { dif. }\end{array}$ & $\eta^{2}$ \\
\hline Never or almost never (a) & 1.337 & 2.56 & Between groups & 3 & 0.498 & 4.72 & 0.00 & $\mathrm{~d}-\mathrm{b}$ & 0.06 \\
\hline Some lessons (b) & 1.433 & 2.55 & Within groups & 4,078 & 0.105 & & & & \\
\hline Many lessons (c) & 925 & 2.59 & Total & 4.081 & & & & & \\
\hline Every lesson or almost every lesson (d) & 387 & 2.61 & & & & & & & \\
\hline
\end{tabular}

at home. Other similar studies have found that books have positive effects on scientific literacy (Ozer and Anil, 2011; Kaya and Dogan, 2016) and mathematics literacy (Ozer and Anil, 2011). In addition, this study showed that there was a significant relationship between both classic literature and books on art, music, or design that students had at home and EL. On the other hand, this study highlighted that there was no significant relationship between both books of poetry and books to help with school work at home. Furthermore, classic literature and books on art, music, or design that students had at home had greater positive effects on EL. Ozer and Anil (2011) claimed that there is a relationship between scientific literacy and educational materials that students have at home, but there was no relationship between mathematics literacy and educational materials. It can be stated that having books to help with school work at home does not affect EL since education is not examination oriented in Germany. Furthermore, as reported by Abdu-Raheem (2015), there is a relationship between the academic performance of students and the SEC of their families. This research also showed that there was a significant relationship between EL and SEC. A similar finding was mentioned by Erbas et al. (2012). Turkish students' responsibility toward the environment varies by SEC. In a similar vein, Lin and Shi (2014) mentioned that economic, social, and cultural status, internal student factors, seem to affect certain aspects of EL. This study found that students' SEC affected their EL, and as SEC increases, EL increases. Studies have indicated that SEC has a significant effect (Hattie, 2003) and its importance for teaching (Lotz and Lipowsky, 2015). Lotz and Lipowssky (2015) in an updated study of Hattie's (2003) study found the effect size between student achievement and SEC (such as family resources) was $d=0.52$. Consequently, these results show that SEC is effective in both student achievement and EL. 


\section{Conclusion and Discussion about TC that Influences EL}

The link between students and teachers is important to the attainment of educational goals (Nembhard, 2005). An important part of the responsibility for strengthening this bond belongs to teachers. For this reason, raising the educational standards of teachers, who are schools' most important resource, is critical (OECD, 2009b). The instructional quality of the teacher has a powerful effect on achievement (Hattie, 2003). In particular, the teaching process should be supported to improve the quality of education. Thus, educators are exploring ways to create schools that improve the learning and performance of students in many parts of the world (Whole Schooling Research Project, 2000). The character of a teacher is also significant for effective teaching practices in enriched learning environments (Pennock and Moyers, 2012). This study's results provided evidence that there was a significant relationship between teachers adapting lessons to their students' needs and knowledge, changing the structure of their lessons, providing individual help when students have difficulties, and explaining science ideas in every lesson and EL. In fact, research has identified these characteristics as effective teacher skills. Sprague (2012) stated about effective teachers that "they can adapt or differentiate instruction for all students by using some basic problem-solving techniques that involve quickly identifying issues, generating alternative solutions, and trying one or two to see if they work" (p. 3).

On the other hand, this study's findings suggest that there was no meaningful relationship between teachers continuing to lecture in their science lessons and EL. The reason for this may be that students want a student-centered learning environment instead of a teacher-centered learning environment. In addition, various approaches can be used for student-centered learning, including case-based learning, project-based learning, and problem-based learning (Pederson and Liu, 2003). These environments focus on meaning formation, inquiry, and authentic activity, unlike traditional teaching (Garrett, 2008). These environments acknowledge each student can learn, research, and analyze current knowledge in a different way (Attard et al., 2010).

Ultimately, individual support given by teachers has a positive effect on EL. For this reason, teachers should create atmospheres where students are supported. Although lecturing does not affect EL, teachers' explanations of scientific ideas in science lessons increase EL. Adapting all lessons to the needs of the students and changing the structure of lessons accordingly can help students to increase their EL.

\section{DIDACTICAL RECOMMENDATIONS}

According to the results, it might be concluded that the environmental literate individual needs awareness and responsibility toward the environment, as well as, to be optimistic toward the environment. Therefore, the knowledge and awareness levels of students should be increased to educate more environmentally literate individuals. The relationship between EL and EO is also positive and meaningful. However, it is also apparent that they are more concerned about environmental issues. Therefore, they should be encouraged to increase their knowledge and awareness about the environment as well as to develop positive emotions toward the environment to remove or reduce environmental concerns. Increasing their optimism about the environment will contribute to higher EL.

States and schools should be aware of the effect of SEC on EL. Governments should provide books to students of low socioeconomic status. Science teachers should also be aware of the effect of SEC on EL and enrich the teaching methods and materials used in their lessons. For instance, the use of musical instruments by science teachers during EE may increase EL levels.

Furthermore, the teaching profession starts with pre-service training and continues with in-service training (Kaya and Gödek, 2016; Kaya, 2011). Therefore, teacher training and practices should be developed to teach environmental issues in teacher education. Similarly, teachers should also be supported by in-service teacher education.

\section{REFERENCES}

American Psychological Association. (2017). Education and Socioeocomic Status. Available from: http://www.apa.org/pi/ses/resources/ publications/factsheet-references.aspx. [Last accessed on 2018 Apr 26].

Atabek-Yigit, E., Koklukaya, N., Yavuz, M., \& Demirhan, E. (2014). Development and validation of environmental literacy scale for adults (Elsa). Journal of Baltic Science Education, 13(3), 425-435.

Key, S., Ma, J.K.C., \& Drake, P.M.W. (2008). Genetically modified plants and human health. Journal of the Royal Society of Medicine, 101(6), 290-298.

Abdu-Raheem, B.O. (2015). Parents' socio-economic status as predictor of secondary school students' academic performance in Ekiti State, Nigeria. Journal of Education and Practice, 6(1), 123-129.

Attard, A., Di loio, E., Geven, K., \& Santa, R. (2010). Student-Centered Learning An Insight Into Theory and Practice. Bucharest, Romania: European Students' Union and Education International.

Bal, B., \& Basar, E. (2014). Comparison of Transition Systems between Finland, Germany, Singapore and Turkish Education Systems. Retrieved from Ç.U. Turkoloji-Article Information System (Number 18777).

Barton, P.E. (2009). National Education Standards: Getting Beneath the Surface. Available from: https://www.ets.org/Media/Research/pdf/ PICNATEDSTAND.pdf.

Büyüköztürk, Ş. (2009). Sosyal Bilimler İçin Veri Analizi El Kitabı (10. Baski). Ankara, Turkey: Pegem Akadenmi Yayıncılık.

Bybee, R., \& Fuchs, B. (2006). Preparing the $21^{\text {st }}$ century workforce: A new reform in science and technology education. Journal of Research in Science Teaching, 43(4), 349-352.

Bybee, R., \& McCrae, B. (2011). Scientific literacy and student attitudes: Perspectives from PISA 2006 science. International Journal of Science Education, 33(1), 7-26.

Chivian, E., \& Bernstein, A. (2010). How our Health Depends on Biodiversity. Available from: http://www.sante-biodiversite.vetagrosup.fr/wp-content/uploads/how-our-health-depends-on-biodiversity. pdf. [Last accessed on 2017 Apr 14].

Coyle, K. (2005). Environmental Literacy in America. Washington, DC: The National Environmental Education \& Training Foundation.

Daniš, P. (2013). New definition of environmental literacy and proposal for its international assessment in PISA 2015. Envigogika: Charles University E-Journal for Environmental Education, 8(3), 1-16.

David, T.G. (1974). Environmental literacy. American Journal of Education, 82(4), 687-705. 
Derman, A., Sahin, E., \& Hacieminoglu, E. (2016). Does outdoor education make any difference in environmental literacy of pre-service classroom teachers? International Journal of Environmental and Science Education, 11(15), 8491-8506. Available from: http://www.eds.a.ebscohost.com. esf.idm.oclc.org/eds/pdfviewer/pdfviewer?sid=8a27743e-0c52-44009878-3fle 91 ca935b\%40sessionmgr4006\& vid $=2 \&$ hid $=4203$.

Dobrota, M., Jeremić, V., Bulajić, M., \& Radojičić, Z. (2015). Uncertainty and sensitivity analyses of PISA efficiency: Distance based analysis approach. Acta Polytechnica Hungarica, 12(3), 41-58.

Erbas, A.K., Tuncer, T.G., \& Tekkaya, C. (2012). An evaluation of environmental responsibility and its associated factors: Reflections from PISA 2006. Egitim Arastirmalart-Eurasian Journal of Educational Research, 46, 41-62.

Eryigit, A., Tekkaya, C., \& Sahin, E. (2011). Elementary School Students from a Developing Country: How do they Expect Environmental Futures to be? Berlin, Germany: Paper presented at the European Conference on Educational Research. pp. 13-16.

Eurydice, M. (2010). Glossary on Education Institutions, Examinations, Qualifications, Titles and Other Specialist Terms. Secretariat of the Standing Conference of the Ministers of Education and Cultural Affairs of the Länder in the Federal Republic of Germany, Documentation and Education Information Service.

Fah, L.Y., \& Sirisena, A. (2014). Relationships between the knowledge, attitudes, and behaviour dimensions of environmental literacy: A structural equation modeling approach using smartpls. Journal for Educational Thinkers, 5, 119-144.

Filho, W.L. (2009). Towards the Promotion of Education for Sustainability. Available from: http://www.revistaeducacion.mec.es/re2009/ re2009 12eng.pdf. [Last accessed on 2018 Apr 26].

Garrett, T. (2008). Student-centered and teacher-centered classroom management: A case study of three elementary teachers. Journal of Classroom Interaction, 43(1), 34-47.

Goss, L. (2010). Eco-friendly Alternatives for Feeding 9 Billion People. St Louis, MO: Washington University, Research Project.

Haan, G.D., Schavan, A., Fuchs, M., \& Bory-adams, A. (2007). UNESCO Today: The UN Decade of Education for Sustainable Development Contributions from Germany. Available from: https://www.unesco. de/en/infothek/publikationen/unesco-heute/uh-2007en.html. [Last accessed on 2018 Mar 21].

Hainmüller, B. (2003). The Educational Structure of the German School System. Offenburg, Germany: Offenburg Teachers Training College.

Halász, G., Santiago, P., Ekholm, M., Matthews, P., \& McKenzie, P. (2004). Attracting, Developing and Retaining Effective Teachers Country Note: Germany. Paris: Organisation for Economic Co-operation and Development Directorate for Education and Training Policy Division.

Hattie, J.A.C. (2003). Teachers Make a Difference: What is the Research Evidence? Available from: https://www.research.acer.edu.au/cgi/ viewcontent.cgi? article $=1003 \&$ context $=$ research_conference_2003. [Last accessed on 2018 May 04].

Hedrick, P.W. (2001). Invasion of transgenes from salmon or other genetically modified organisms into natural populations. Canadian Journal of Fisheries and Aquatic Sciences, 58(5), 841-844.

Hollweg, K.S., Taylor, J.R., Bybee, R.W., Marcinkowski, T.J., McBeth, W.C., \& Zoido, P. (2011). Developing a Framework for Assessing Environmental Literacy. Washington, DC: North American Association for Environmental Education.

Huber, S.G., \& Gördel, B. (2006). Quality assurance in the German school system. European Educational Research Journal, 5(3), 196-209.

Ivanova, M., \& Roy, J. (2007). The Architecture of Global Environmental Governance: Pros and Cons of Multiplicity. Available from: http://www. centerforunreform.org/?q=node/234. [Last accessed on 2018 Apr 26].

Karagoz, Y. (2016). SPSS and AMOS 23 Applied Statistical Analyzes. Ankara, Turkey: Nobel Publishing.

Katsara, O. (2015). Reaffirming the Teacher Role within the Context of Culturally Responsive Pedagogy: A Case Study and Relevant, ELTWorldOnline.com, 7, 1-23.

Kaya, V.H. (2011). The Views Concerning the Factors which Effect Science and Technology Teachers' Professional Development (Master's Thesis, Ahi Evran University, Institute of Sciences, Kirsehir, Turkey).

Kaya, V.H., \& Dogan, A. (2016). Determination and Comparison of Turkish
Student Characteristics Affecting Science Literacy in Turkey According to PISA 2012. Paper Presented at the International Conference on Quality in Higher Education, Sakarya, Turkey. pp. 24-25.

Kaya, V.H., \& Gödek, Y. (2016). Perspectives in regard to factors affecting the professional development of science teachers. Journal of Human Sciences, 13(2), 2625.

Kaya, V.H., \& Kazanc1, E. (2009). Ekolojik okuryazarlık. TÜBİTAK Bilim ve Teknik Dergisi, Ylldız Takımı, 11, 14-15.

Kocak, M., \& Cobanogulları, F. (2016). The schools, so-called "Realschule", in German education system. Education and Society in the $21^{\text {st }}$ Century, 5(6), 163-176.

Likens, G.E., \& Bormann, F.H. (1974). Acid rain: A serious regional environmental problem. Science, 184(4142), 1176-1179.

Lin, E., \& Shi, Q. (2014). Exploring individual and school-related factors and environmental literacy: Comparing U.S. and Canada using PISA 2006. International Journal of Science and Mathematics Education, 12, 73-97.

Lotz, M., \& Lipowsky, F. (2015). Die Hattie-Studie und ihre Bedeutung für den Unterricht-Ein Blick auf ausgewählte Aspekte der Lehrer-SchülerInteraktion. In: Mehlhorn, G., Schulz, F., \& Schöppe, K., (Eds.), Begabungen Entwickeln and Kreativität Fördern. München: Kopaed. pp. 97-136.

Meydan, C.H., \& Sesen, H. (2015). Structural Equation Modeling-AMOS Applications. Ankara, Turkey: Detay Publishing.

Nembhard, J.P. (2005). Bonding: The teacher-student-parent connection. Journal of Adventist Education, 68(1), 18-20.

OECD (2016), PISA 2015 Assessment and Analytical Framework: Science, Reading, Mathematic and Financial Literacy. Paris: OECD Publishing.

OECD, (2009b). Teacher Evaluation a Conceptual Framework and Examples of Country Practices. Paris: OECD Publications.

OECD. (2000a). Measuring Student Knowledge and Skills, The PISA 2000 Assessment of Reading, Mathematical and Scientific Literacy. Paris: OECD Publications.

OECD. (2000b). Knowledge and Skills for Life First Results from PISA 2000. Paris: OECD Publications.

OECD. (2002a). Sample Task form the PISA 2000 Assessment of Reading, Mathematical and Scientific Literacy. Paris: OECD Publications.

OECD. (2002b). PISA 2000 Technical Report. Paris: OECD Publications.

OECD. (2003). Literacy Skills for the World of Tomorrow Further Results from PISA 2000. Paris: OECD Publications.

OECD. (2004). Learning for Tomorrow's World First Results from PISA 2003. Paris: OECD Publications.

OECD. (2006). Assessing Scientific, Reading and Mathematical Literacy a Framework for PISA 2006. Paris: OECD Publications.

OECD. (2009a). Take the Test Sample Questions from OECD's PISA Assessments. Paris: OECD Publications.

OECD. (2010). Germany: Once Weak International Standing Prompts Strong Nationwide Reforms for Rapid Improvement. Paris: OECD Publications.

OECD. (2013). PISA 2012 Assessment and Analytical Framework: Mathematics, Reading, Science, Problem Solving and Financial Literacy. Paris: OECD Publishing.

Oral, I., \& McGivney, E. (2013). Performance of Student and Determinants of Success in Mathematics and Science Fields in Turkey, Analysis of TIMSS 2011. Ankara, Turkey: Eğitim Reformu Girişimi.

Ozer, Y., \& Anil, D. (2011). Examining the factors affecting students' science and mathematics achievement with structural equation modeling. Hacettepe University Journal of Education, 41, 313-324.

Ozsevgec, T., Artun, H., \& Ozsevgec, L.C. (2010). Development of environmental literacy scale for prospective teachers. Educational Research, 1(8), 239-245.

Pant, H.A., Stanat, P., Schroeders, U., Roppelt, A., Siegle, T., \& Pöhlmann, C. (Eds.). (2013). The IQB National Assessment Study 2012 Competencies in Mathematics and the Sciences at the End of Secondary Level I Summary. New York: Waxmann.

Patz, J.A., Githeko, A.K., McCarty, J.P., Hussein, S., Confalonieri, U., \& De Wet, N. (2003). Climate change and infectious diseases. Climate change and human health: risks and responses. Available from: http:// www.who.int/globalchange/publications/cchhbook/en/. [Last accessed on 2018 Apr 28].

Pe'er, S., Goldman, D., \& Yavetz, B. (2007). Environmental literacy in 
teacher training: Attitudes, knowledge, and environmental behavior of beginning students. The Journal of Environmental Education, 39(1), 45-59.

Pederson, S., \& Liu, M. (2003). Teachers' beliefs about issues in the implementation of a student-centered learning environment. Educational Technology Research and Development, 51(2), 57-76.

Pennock, A.J., \& Moyers, K.L. (2012). The Role of Personality in K-12 Education. Proceedings of the $19^{\text {th }}$ Annual American Society of Business and Behavioral Sciences (ASBBS) Conference, Las Vegas, Nevada, 19(1), 710-714. Available from: http://www.asbbs.org/files/ ASBBS2012V1/PDF/P/PennockA.pdf. [Last accessed on 2018 Mar 29].

PISA. (2013). PISA 2015 Draft Science Framework. Available from: https://www.oecd.org/pisa/pisaproducts/Draft\%20PISA\%202015\%20 Science\%20Framework\%20.pdf. [Last accessed on 2018 Apr 26].

PISA. (2017). PISA 2015 Draft Questionnaire Framework. Available from: $\mathrm{http} / /$ www.oecd.org/pisa/pisaproducts/PISA-2015-draft-questionnaireframework.pdf. [Last accessed on 2018 Apr 14].

Polat, D., Kaya, V.H., \& Karamuftuoglu, O. (2014). Perceptions of Undergraduate and Master Students Towards Conservation of Nature. Adana, Turkey: Paper presented at the $11^{\text {th }}$ National Science and Mathematics Education Congress.

Recommendations to the National Center for Education Statistics. (2012). Improving the Measurement of Socioeconomic Status for the National Assessment of Educational Progress: A Theoretical Foundation. Available from: https://www.nces.ed.gov/nationsreportcard/pdf/ researchcenter/Socioeconomic_Factors.pdf. [Last accessed on $2018 \mathrm{Apr}$ 26].

Roberts, D.A. (2007). Scientific literacy/science literacy. In: Abell, S.K., \& Lederman, N.G., (Eds.), Handbook of Research on Science Education. Mahwah, N.J: Lawrence Erlbaum Associates. pp. 729-780.

Roth, C.E. (1992). Environmental Literacy: Its Roots, Evolution and Directions in the 1990s. Columbus, OH: ERIC Clearinghouse for Science, Mathematics and Environmental Education. (ED348235).

Schermelleh-Engel, K., Moosbrugger, H., \& Müler, H. (2003). Evaluating the fit of structural equation models: Tests of significance and descriptive goodness-of-fit measures. Methods of Psychological Research Online, $8(2), 23-74$

Schleicher, K. (1995). Trends and current state of environmental education in Germany. In: Bos, W., \& Lerman, R., (Eds.), Reflections on Educational Achievement. New York: Waxman. pp. 230-255.

Schneider, S.H. (1997). Defining and teaching environmental literacy. Trends in Ecology and Evolution (TREE), 12(11), 457.

Scholz, R.W. (2011). Environmental Literacy in Science and Society from Knowledge to Decisions. Cambridge: Cambridge University Press.

Sekretariat der Standigen Konferenz der Kultusminister der Lander in der Bundesrepublik Deutschland (KMK). (2005). Beschlüsse der Kultusministerkonferenz-Bildungsstandards im Fach Biologie für den Mittleren Bildungsabschluss (Beschluss vom 16. Dezember 2004). Munchen: Wolters Kluwer.

Spínola, H. (2015). Environmental literacy comparison between students taught in eco-schools and ordinary schools in the Madeira Island region of Portugal. Science Education International, 26(3), 392-413.

Sprague, J. (2012). The nexus of student behavior and teacher behavior adapting curriculum and instruction: A primer. The Special Education Digest, 25(2), 3-7.

Stoller-Patterson, A.L. (2012). Educating for Environmental Literacy in America's Public Schools. Available from: http://www.scholarship. claremont.edu/pomona_theses/42/. [Last accessed on 2018 Apr 28].

Subbarini, M.S. (1998). Philosophical, Epistemological, Doctrinal and Structural Basis for International Environmental Education Curriculum. Proceedings of the International Best of Both Worlds Conference (Pretoria, South Africa, March 1998). Presented by the University of South Africa, Vista University, and the South African College of Education.

Taylor, S., \& Yu, D. (2009). The Importance of Socio-economic Status in Determining Educational Achievement in South Africa. Available from: https://www.ideas.repec.org/p/sza/wpaper/wpapers73.html. [Last accessed on 2018 Aug 26].

Tuncer, G., Tekkaya, C., Sungur, S., Cakiroglu, J., Ertepinar, H., \& Kaplowist, M. (2009). Assessing pre-service teachers' environmental literacy in Turkey as a means to develop teacher education programs. International Journal of Educational Development, 29, 426-436.

Turan, K. (2005). The comparison and evaluation of Turkish-German educational systems the process of entrance to EU. Journal of National Education, 167. Available from: https://www.dhgm.meb.gov.tr/ yayimlar/dergiler/Milli_Egitim_Dergisi/167/index3-turan.htm. [Last accessed on $2017 \mathrm{Feb} 10]$.

UNESCO. (2014). UN Decade with Impact-10 Years of Education for Sustainable Development in Germany. Bonn: German Commission for UNESCO (DUK).

UNESCO-UNEP. (1992). Environmental Education Activities for Primary Schools Suggestions for Making and using low-Cost Equipment. Available from: http://www.unesdoc.unesco.org/images/0009/000963/096345eo. pdf. [Last accessed on 2018 Apr 13].

Venter, J. (1987). Teacher education system in the Federal Germany today. Hacettepe University Journal of Education, 2, 105-110.

Wenshun, W., Xiaohua, L., \& Hualong, L. (2011). Empirical research of the environmental responsibility affected on the urban residential housing energy saving investment behavior. Energy Procedia, 5, 991-997.

Whole Schooling Research Project. (2000). Key Elements to Building an Inclusive School, Renaissance. Detroit, MI: Community Press, Wayne State University.

Yavetz, B., Goldman, D., \& Pe'er, S. (2009.). Environmental literacy of preservice teachers in Israel: a comparison between students at the onset and end of their studies. Environmental Education Research, 15(4), 393-415.

Zhao, N., Valcke, M., Desoete, A., \& Verhaeghe, J. (2012). The quadratic relationship between socioeconomic status and learning performance in China by multilevel analysis: Implications for policies to foster education equity. International Journal of Educational Development, $32,412-422$ 


\section{APPENDICES}

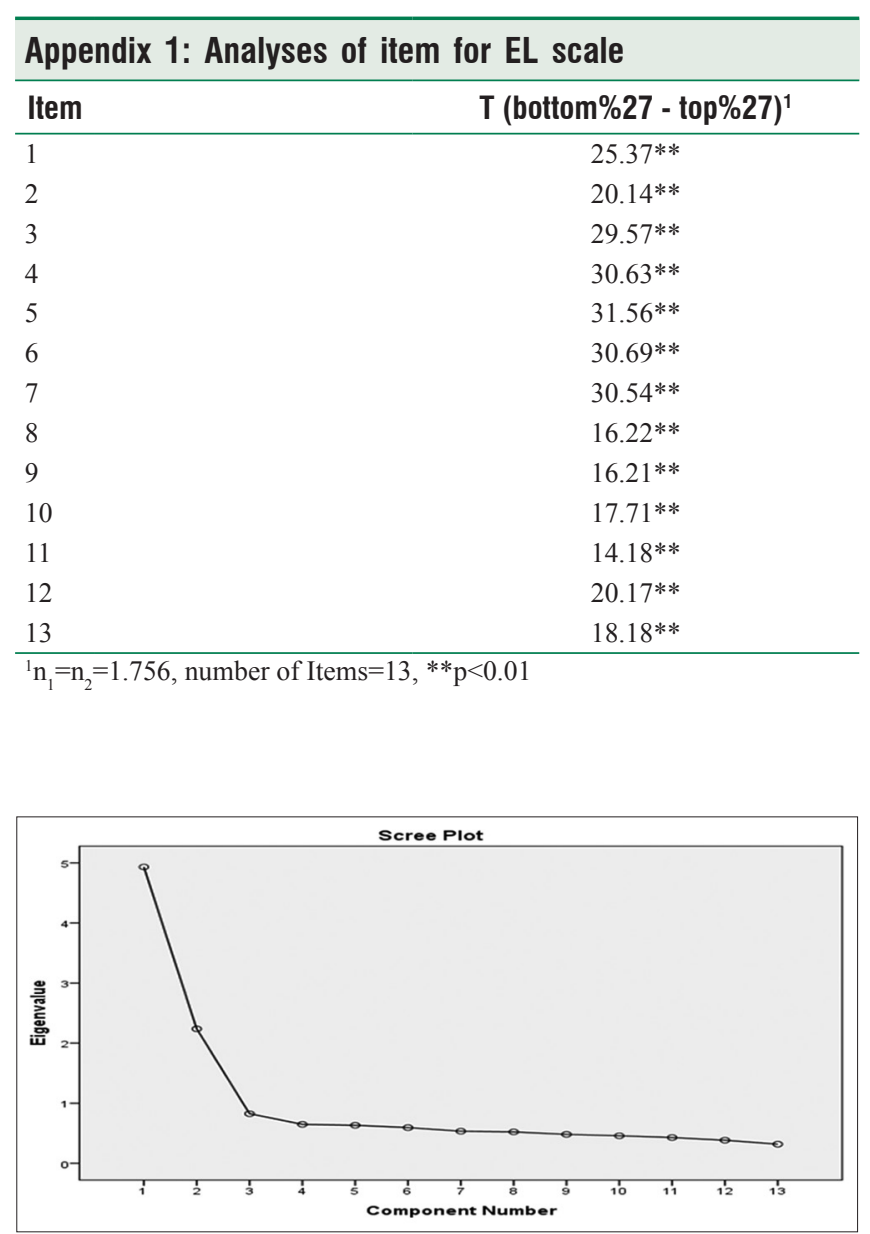

Appendix 2: Graphic of eigenvalues for EL scale

\section{Appendix 3: Correlation between EL and EO}

\section{EA}

ER

\begin{tabular}{rccc} 
& EA & ER & EL \\
\hline EA & & & \\
R & 1 & & \\
$P$ & & & \\
$N$ & 6504 & & \\
ER & & & \\
R & $-0.38^{* *}$ & 6504 & \\
P & 0.00 & & \\
$N$ & 6504 & $0.43^{* *}$ & 1 \\
EL & & 0.00 & \\
R & $0.67^{* *}$ & 6504 & 6504 \\
$P$ & 0.00 & & \\
$\mathrm{~N}$ & 6504 & & \\
\hline
\end{tabular}

\begin{tabular}{lc}
\hline \multicolumn{2}{l}{ Appendix 4: Analyses of item } \\
\hline Item & T (bottom\%27 - top\%27) ${ }^{1}$ \\
\hline 1 & $5.00^{* *}$ \\
2 & $4.55^{* *}$ \\
3 & $4.80^{* *}$ \\
4 & $7.45^{* *}$ \\
5 & 0.82 \\
6 & $4.30^{* *}$ \\
7 & $2.5^{* *}$ \\
\hline${ }^{{ }}{ }_{1}=\mathrm{n}_{2}=1.756$, number of items $=13, * * \mathrm{p}<0.01$ &
\end{tabular}

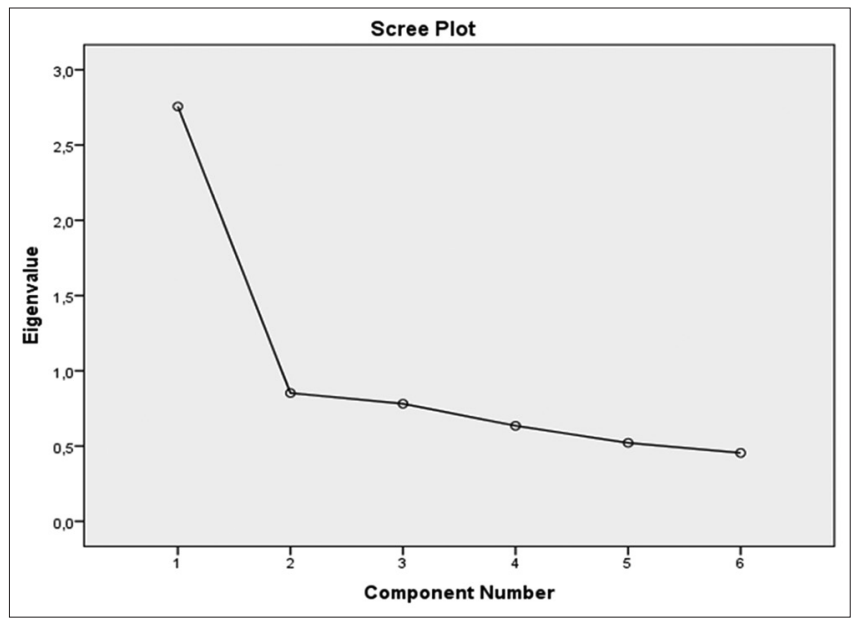

Appendix 5: Graphic of eigenvalues

\begin{tabular}{lcccc}
\hline \multicolumn{7}{l}{ Appendix 6: Mean of factors } \\
\hline Statistics & EA & ER & EL & EO \\
\hline Mean & 2.86 & 2.28 & 2.57 & 2.46 \\
Maximum value & 1.00 & 1.00 & 1.00 & 1.00 \\
Minimum value & 4.00 & 4.00 & 4.00 & 3.00 \\
\hline
\end{tabular}

\section{Appendix 7: Correlation between EL and EO}

EL E0

\begin{tabular}{rrr}
\hline EL & & \\
$\mathrm{R}$ & & \\
$\mathrm{P}$ & & \\
$\mathrm{N}$ & & \\
$\mathrm{EO}$ & 0.16 & 1 \\
$\mathrm{R}$ & 0.00 & \\
$\mathrm{P}$ & 6504 & 6504 \\
$\mathrm{~N}$ & \\
\hline
\end{tabular}




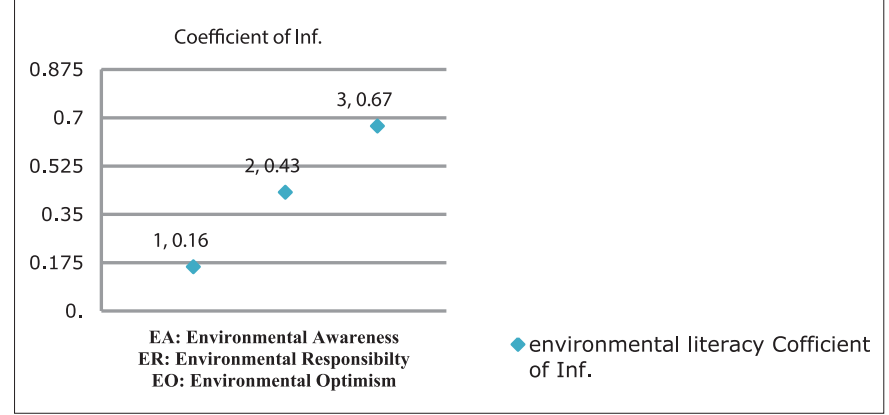

Appendix 8: Correlation coefficients

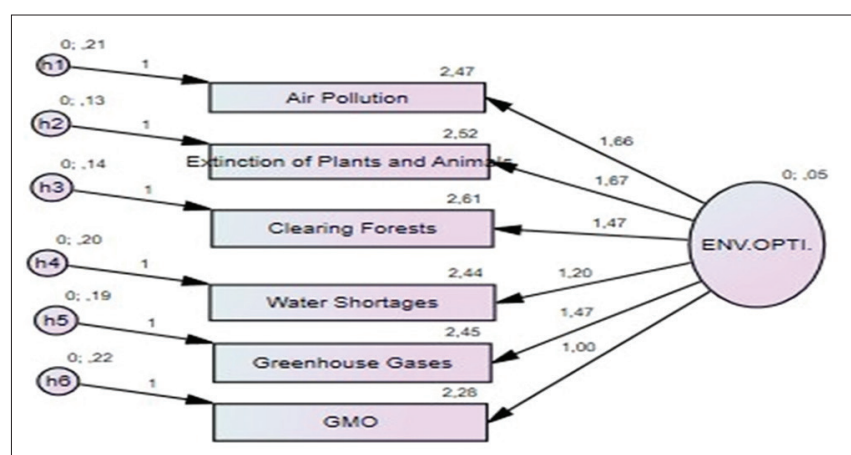

Appendix 9: Views on E0 